\title{
Fabrication and Antibacterial Performance of Graded Nano-Composite Biomaterials
}

\author{
Anping $\mathrm{Xu}$ and Dongbin Zhu \\ School of Mechanical Engineering, Hebei University of Technology, Tianjin, \\ China
}

\section{Introduction}

Solid freeform fabrication (SFF), also termed as layered manufacturing, produces parts directly from a computer model without part-specific tooling and human intervention (Sachlos et al., 2003; Leong et al., 2003; Kim et al., 2009; Dwivedi and Kovacevic, 2004; Cai et al., 2003; Tian et al., 2002; Guo et al., 2002; Cawley, 1999; Calvert et al., 1998; Alimardani and Toyserkani, 2008; Alemohammad et al., 2007; Li, 2005; Bryant et al., 2003). It has great potential to fabricate functionally graded materials (FGMs).

Through selective slurry extrusion (SSE) based technique of SFF, Xu et al. successfully fabricated multi-material dental crown (Xu et al., 2005) and further proposed a novel approach (as shown in Figure 1), termed as equal distance offset (EDO), to representing and process planning for SFF of functionally graded materials so as to meet the requirement of modelling and fabricating 3D complex shaped FGM objects ( $\mathrm{Xu}$ and Shaw, 2005).

In EDO (Xu and Shaw, 2005), a neutral arbitrary 3D CAD model is adaptively sliced into a series of 2D layers. Within each layer, 2D material gradients are designed and represented via dividing the $2 \mathrm{D}$ shape into several sub-regions enclosed by iso-composition contours. If needed, the material composition gradient within each of the sub-regions can be further specified by applying the equal distance offset algorithm to each sub-region. Using this approach, an arbitrary-shaped 3D FGM object with linear or non-linear composition gradients can be represented and fabricated via suitable SFF machines. The process planning for SFF of FGM objects is shown in Figure 2.

In recent years, the inkjet colour printing based SFF technology has been of great interests in tissue engineering (Calvert et al., 2007; Xu et al., 2006; Saunders et al., 2008; Sanchez et al., 2008; Roth, 2004; Hasenbank et al., 2008; Cui and Boland, 2009), as it can fabricate 3D complex shaped graded material with smooth gradients (Wang and Shaw, 2006).

Human teeth have some very good properties such as high hardness and wearability, good heat insulation, high strength, etc. These properties are related to its graded structure. Figure 3 (Tooth anatomy, (2011). http://www.mydr.com.au/first-aid-self-care/toothanatomy) shows a drawing of a healthy tooth cut in half lengthways, which shows the layers of the tooth and its internal structure, as well as how the tooth relates to the gum and surrounding jaw bone. 


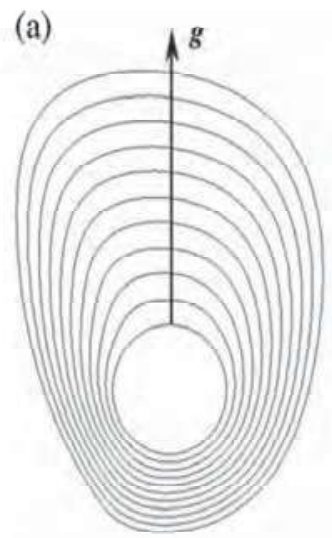

(b)

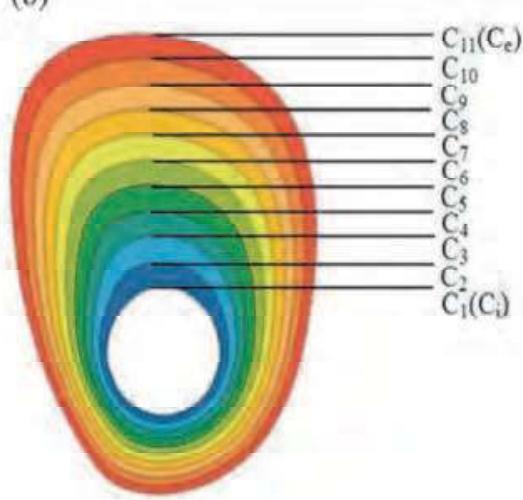

\begin{tabular}{|l|}
\hline$S_{2011}$ \\
\hline$S_{2,10}$ \\
\hline$S_{2,9}$ \\
\hline$S_{2,1}$ \\
\hline$S_{21}$ \\
\hline$S_{2,0}$ \\
\hline$S_{2,3}$ \\
\hline$S_{2,1}$ \\
\hline$S_{2,3}$ \\
\hline$S_{2,2}$ \\
\hline
\end{tabular}

Fig. 1. EDO approach to representing functionally graded material objects.

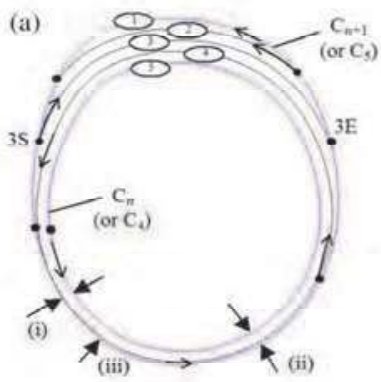

(b)

(c)
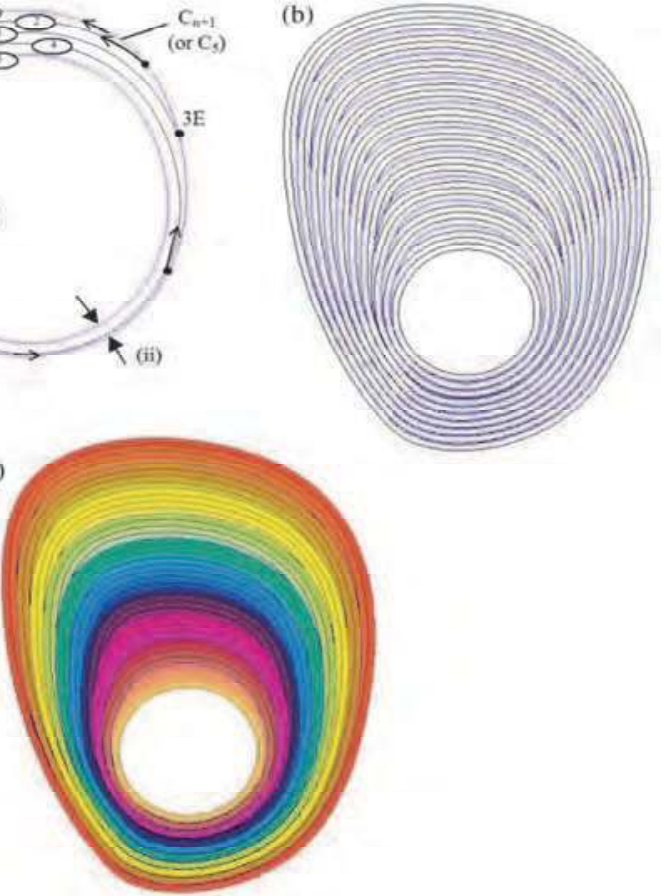

Fig. 2. Process planning for SFF of FGM objects. 
A normal tooth can be divided into three parts: the crown, the neck and the root. The crown is the part of the tooth that is visible above the gum (gingiva). The neck is the region of the tooth that is at the gum line, between the root and the crown. The root is the region of the tooth that is below the gum. Some teeth have only one root, for example, incisors and canine (eye) teeth, whereas molars and premolars have 4 roots per tooth.

The crown of each tooth has a coating of enamel, which protects the underlying dentine. Enamel is the hardest substance in the human body, harder even than bone. It gains its hardness from tightly packed rows of calcium and phosphorus crystals within a protein matrix structure. Once the enamel has been formed during tooth development, there is little turnover of its minerals during life. Mature enamel is not considered to be a 'living' tissue.

The major component of the inside of the tooth is dentine. This substance is slightly softer than enamel, with a structure more like bone. It is elastic and compressible in contrast to the brittle nature of enamel. Dentine is sensitive. It contains tiny tubules throughout its structure that connect with the central nerve of the tooth within the pulp. Dentine is a 'live' tissue.

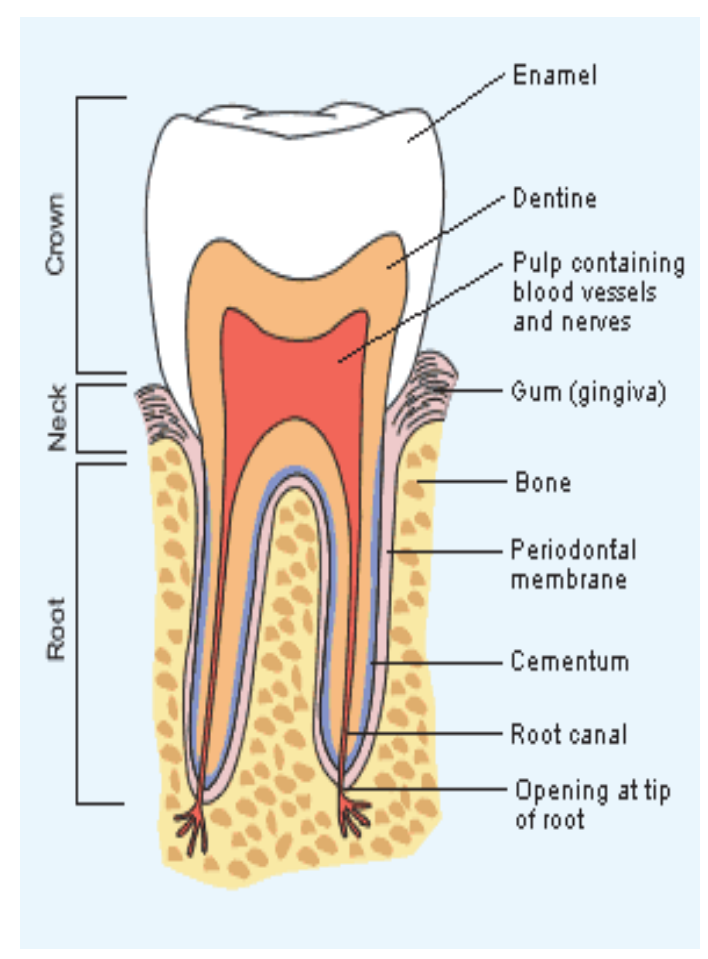

Fig. 3. Internal structure of a normal tooth. 
Below the gum, the dentine of the root is covered with a thin layer of cementum, rather than enamel. Cementum is a hard bone-like substance onto which the periodontal membrane attaches. This membrane bonds the root of the tooth to the bone of the jaw. It contains elastic fibres to allow some movement of the tooth within its bony socket.

The pulp forms the central chamber of the tooth. The pulp is made of soft tissue and contains blood vessels to supply nutrients to the tooth, and nerves to enable the tooth to sense heat and cold. It also contains small lymph vessels which carry white blood cells to the tooth to help fight bacteria.

The extension of the pulp within the root of the tooth is called the root canal. The root canal connects with the surrounding tissue via the opening at the tip of the root. This is an opening in the cementum through which the tooth's nerve supply and blood supply enter the pulp from the surrounding tissue.

Unfortunately, dental caries is one of the most important problems in human oral diseases (Namba et al., 1982). It is known that streptococcus mutans play one of most important roles in dental caries (Jessica et al., 2007). During metabolizing carbohydrates, streptococcus mutans produces organic acid, which can induce the demineralization of tooth surface and results in dental caries (Ooshima et al., 2000).

Some literatures disclosed that the dental plaque $\mathrm{pH}$ after a sucrose rinse can decrease to 4.5 or even 4 (Hefferren et al., 1981; Thylstrup et al., 1986). A pH of higher than 6 is considered to be the safe area, a plaque $\mathrm{pH}$ of $6.0 \sim 5.5$ is the potentially cariogenic area, and $\mathrm{pH}$ of $5.5 \sim 4$ is the cariogenic or dangerous area for cavity formation. Therefore, the maintenance of a higher $\mathrm{pH}$ value in the plaque is very important for the anticaries.

The fluoride has been used for about five decades in caries prevention. However, it is difficult to control its quantity to a proper level (Nakajo et al., 2008); excessive fluoride is harmful to human body and insufficient fluoride will not take effect for anticaries action. In recent years much attention has been paid to developing fluoride-free techniques that can prevent human teeth from caries(Scherp et al., 1971; Allakera and Ian Douglas, 2009).

Some natural products were reported to be candidates of new anticariogenic substances (Shouji et al., 2000; Matsumoto et al., 1999). However, there is not scientific evidence about the effect of natural tourmaline on the streptococcus mutans.

Tourmaline is a kind of electropolar mineral belonging to the trigonal space group of $\mathrm{R} 3 \mathrm{~m}$, whose general chemical formula can be written as $\mathrm{XY}_{3} \mathrm{Z}_{6} \mathrm{Si}_{6} \mathrm{O}_{18}\left(\mathrm{BO}_{3}\right)_{3} \mathrm{~W}_{4}$, where $\mathrm{X}$ is $\mathrm{Na}^{+}$, $\mathrm{Ca}^{2+}, \mathrm{K}^{+}$, or vacancy; $\mathrm{Y}$ is $\mathrm{Mg}^{2+}, \mathrm{Fe}^{2+}, \mathrm{Mn}^{2+}, \mathrm{Al}^{3+}, \mathrm{Fe}^{3+}, \mathrm{Mn}^{3+}, \mathrm{Cr}^{3+}, \mathrm{Ti}^{4+} \mathrm{Or} \mathrm{Li}^{+}$; $\mathrm{Z}$ is $\mathrm{Al}^{3+}, \mathrm{V}^{3+}$, $\mathrm{Cr}^{3+}$, or $\mathrm{Mg}^{2+}$; and $\mathrm{W}$ is $\mathrm{OH}^{-}, \mathrm{F}^{-}$, or $\mathrm{O}^{2-}$ (Castañeda et al., 2006). Its Crystal structure of tourmaline is shown in Figure 4 (Fuchs et al., 1998).

The most important feature among the electric properties of the tourmaline is the possession of spontaneous and permanent poles, which would produce an electric dipole, especially in a small powder with a diameter of several microns or less (Jin et al., 2003). Therefore, a strong electric field exists on the surface of a tourmaline powder (Nakamura et al., 1994; Zhu et al., 2008). The electric field effect of tourmaline powders can influence the redox potential of water and regulated the $\mathrm{pH}$ value of solution (Xia et al., 2006). The maintenance of $\mathrm{pH}$ value is very important for the growth and metabolism of bacteria (Esgalhado et al., 1995). Therefore, the graded composite materials were fabricated with nano-tourmaline and nano-hydroxyapatite powders by direct inkjet colour printing for the study of inhibiting function on streptococcus mutans. Moreover, the mechanism by which tourmaline inhibits the growth and acid production of streptococcus mutans was also explained from the view of $\mathrm{pH}$ value. 


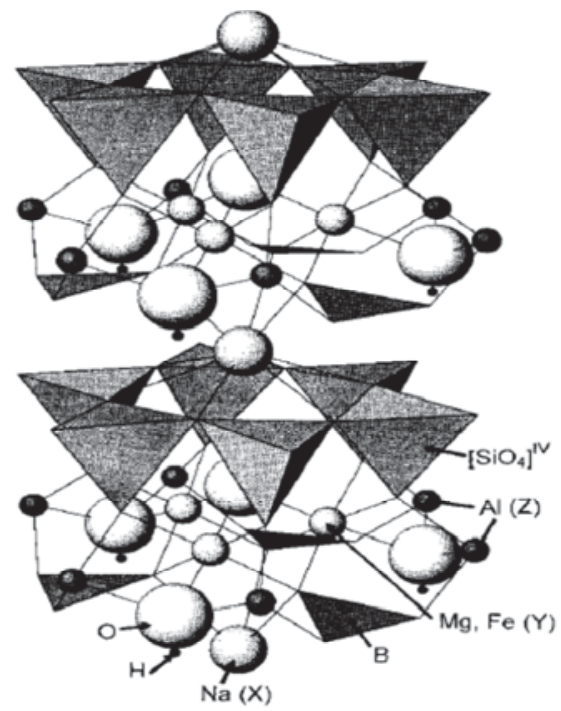

Fig. 4. Crystal structures of tourmaline.

\section{Printing setup}

The printer consists of a printing table and two piezoelectric XJ126 monochromatic print head (Xaarjet Ltd., Cambridge, UK). There are a total of 134 nozzles viewable on the nozzle plate. The active nozzles are numbered 1 to 126, with nozzle 1 referenced to the datum features on the printhead (as shown in Figure 5), linking a ME1+ continuous ink supply system (Epson, Japan) for the different inks.

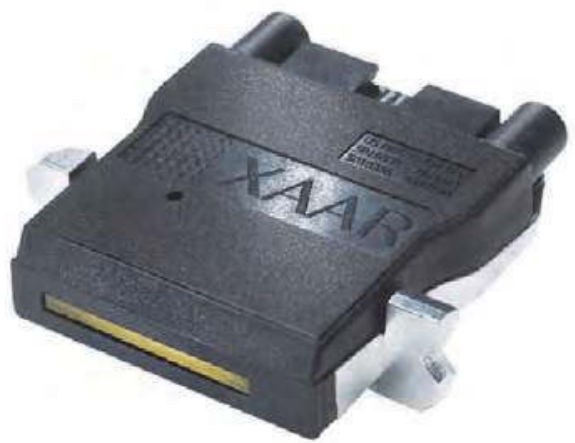

Fig. 5. XJ126 printhead (Courtesy of Xaar. See http://www.xaar.com/xaar126.aspx).

A PC104 Programmable Multi-Axis Controller (Delta Tau Ltd. California, USA) for the sliding table and print head movement, and a XaarJet HPC for print head operation were incorporated. The control program was XUSB application in windows XP. The XJ126 print head is a 126 nozzle, piezoelectric drop-on-demand array of print width $17.14 \mathrm{~mm}$ and 
nozzle diameter $50 \mu \mathrm{m}$. The sliding table moved at $50 \mathrm{~mm} / \mathrm{s}$ for printing. The gap between the nozzle plate and the printing surface was maintained at $1 \mathrm{~mm}$ by $\mathrm{Z}$ displacement. The graded colour pattern was written using Adobe Photoshop software and converted to monochrome binary image files, in device-independent bitmap format, for printing pattern on the substrate. The processing flow of an image is shown in Figure 6.

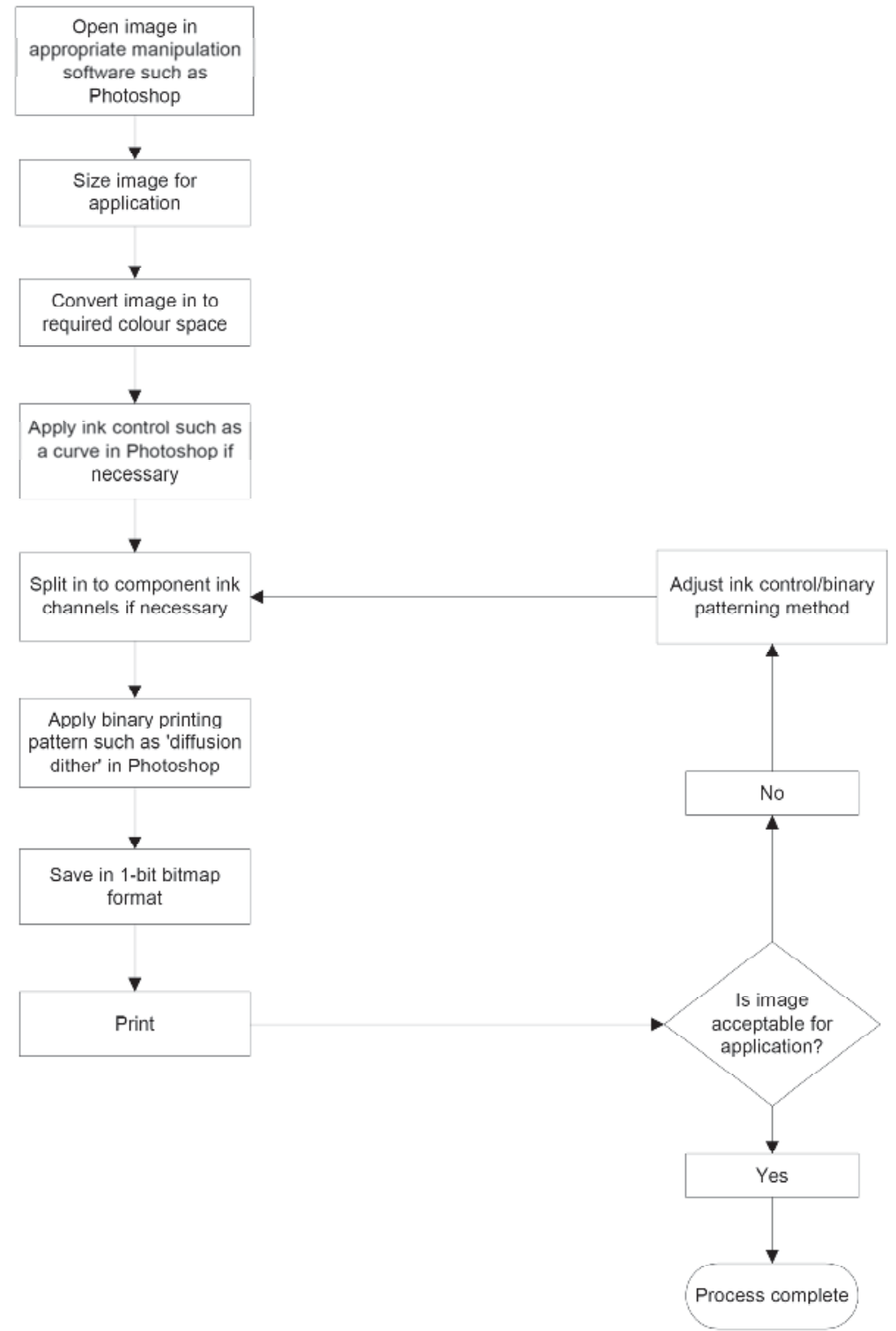

Fig. 6. Processing flow of an image (Courtesy of XAAR, Guide to Operation). 


\section{Materials and methods}

Tourmaline powders were from the Inner Mongolia Autonomous Region of China, whose chemical compositions were analyzed by EDAX Phoenix energy dispersion spectroscope (EDS) and given in the mass ratio as follows: $\mathrm{Al}_{2} \mathrm{O}_{3}, 34.98 \% ; \mathrm{B}_{2} \mathrm{O}_{3}, 10.94 \% ; \mathrm{K}_{2} \mathrm{O}, 0.036 \%$; $\mathrm{Na}_{2} \mathrm{O}, 0.91 \%$; $\mathrm{CaO}, 2.534 \%$; $\mathrm{MgO}, 0.2 \%$; $\mathrm{SiO}_{2}, 34.6 \% ; \mathrm{Fe}_{2} \mathrm{O}_{3}, 15.8 \%$. The preparation of nanohydroxyapatite powders was reported in Ref. (Shih et al., 2004). The streptococcus mutans was purchased from Tianjin Medical University, China. Brain heart infusion (BHI) broth, mitis salivarius agar (MSA) and phenol red broth were purchased from Hangzhou Tianhe Microorganism Reagent Co., Ltd., China. Other reagents were analytical.

These tourmaline and hydroxyapatite inks with ethyl alcohol as the carrier and oleic acid as the dispersant had a solid loading of 15 and $20 \mathrm{wt} \%$, respectively. After mixing the powders in ethyl alcohol, the suspensions were kept in the ultrasonicator for $1 \mathrm{~h}$. Then, sedimentation experiments for more than $24 \mathrm{~h}$ confirmed that this was indeed the case. To provide the visual appreciation of the graded materials fabricated, the tourmaline suspension was mixed with $20 \mathrm{wt} \%$ of the commercial XaarJet magenta ink, whereas the hydroxyapatite suspension was mixed with $20 \mathrm{wt} \%$ of the XaarJet cyan ink. The streptococcus mutans can be cultured on the graded materials.

The compositional profiles were determined using a scanning electron microscope (Philips XL30, Amsterdam, Holland) equipped with energy dispersive spectrometry (EDS). The Xray diffraction (XRD) analysis was performed on a Philips-X'Pert TMD diffractometer with $\mathrm{Cu} \mathrm{Ka}$ radiation $(\lambda=0.154056 \mathrm{~nm})$. The patterns were scanned over the $2 \theta$ angular range $10 \sim 60^{\circ}$ at a scan rate of $0.03^{\circ} 2 \theta \mathrm{s}^{-1}$.

The growth of streptococcus mutans was examined at $37^{\circ} \mathrm{C}$ in $0.95 \mathrm{ml}$ of $\mathrm{BHI}$ broth containing $1 \%$ glucose and various concentrations of tourmaline. These tubes were inoculated with 0.1 $\mathrm{ml}$ of an overnight culture grown in the $\mathrm{BHI}$ broth, and incubated at $37{ }^{\circ} \mathrm{C}$ for 1 day. The optical density (OD) of cells was measured spectrophotometrically at $600 \mathrm{~nm}$.

The filter-sterilized tourmaline was added to $0.95 \mathrm{ml}$ of the phenol red broth containing $1 \%$ glucose, which was then inoculated with $0.05 \mathrm{ml}$ of the seed culture of streptococcus mutans. The cultures were incubated at $37^{\circ} \mathrm{C}$ for 1 day, and the $\mathrm{pH}$ of the cultures was determined using a precise $\mathrm{pH}$ meter (PHS-3B, Shanghai Precision \& Scientific Instrument Co., Ltd., China).

Fifteen grams of tourmaline were added with $100 \mathrm{ml}$ of bacterial suspensions. The initial $\mathrm{pH}$ of the medium was changed between 5.0 and 11.0, whereas the temperature was constant at $37^{\circ} \mathrm{C}$. The $\mathrm{pH}$ of the bacterial suspension at different time was measured with precise $\mathrm{pH}$ meter mentioned above.

Ten replicates were made for each test. Data were analyzed using the statistical package for social sciences (SPSS). The data were expressed by the mean \pm S.D. Differences between means of the experimental and control groups were evaluated by the Student's t-test. The level of significance for statistical analyses was 0.05 .

\section{Results and discussion}

XRD patterns of the tourmaline powder is shown in Figure 7. From Figure 7, we can see that the main crystal structure of the tourmaline powder does not change apparently and no other phase of tourmaline can be found before and after printing, indicating that the crystal structures of tourmaline powders were not changed. Through calculation, the crystal volume had no change either. 


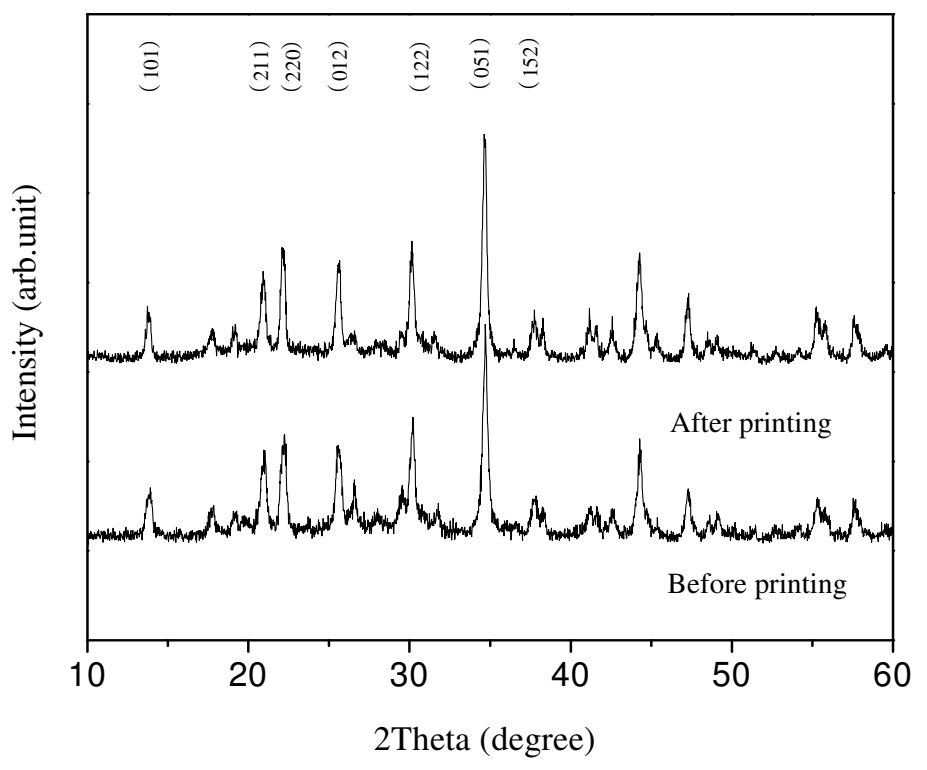

Fig. 7. XRD pattern of tourmaline powders before and after printing.

Graded materials were printed using 10 overprinted layers at a printer defined resolution of 185 dot-per-inch (dpi). As shown in Figure 8(a), the tourmaline in the two graded materials of dimensions $10 \mathrm{~mm} \times 10 \mathrm{~mm}$ increases with a linear gradient from the left to the right. And in Figure 8(b), the tourmaline in the elliptical two graded object increases with a linear gradient from the center to the edges. These compositional profiles of graded materials match that of the design very well. 


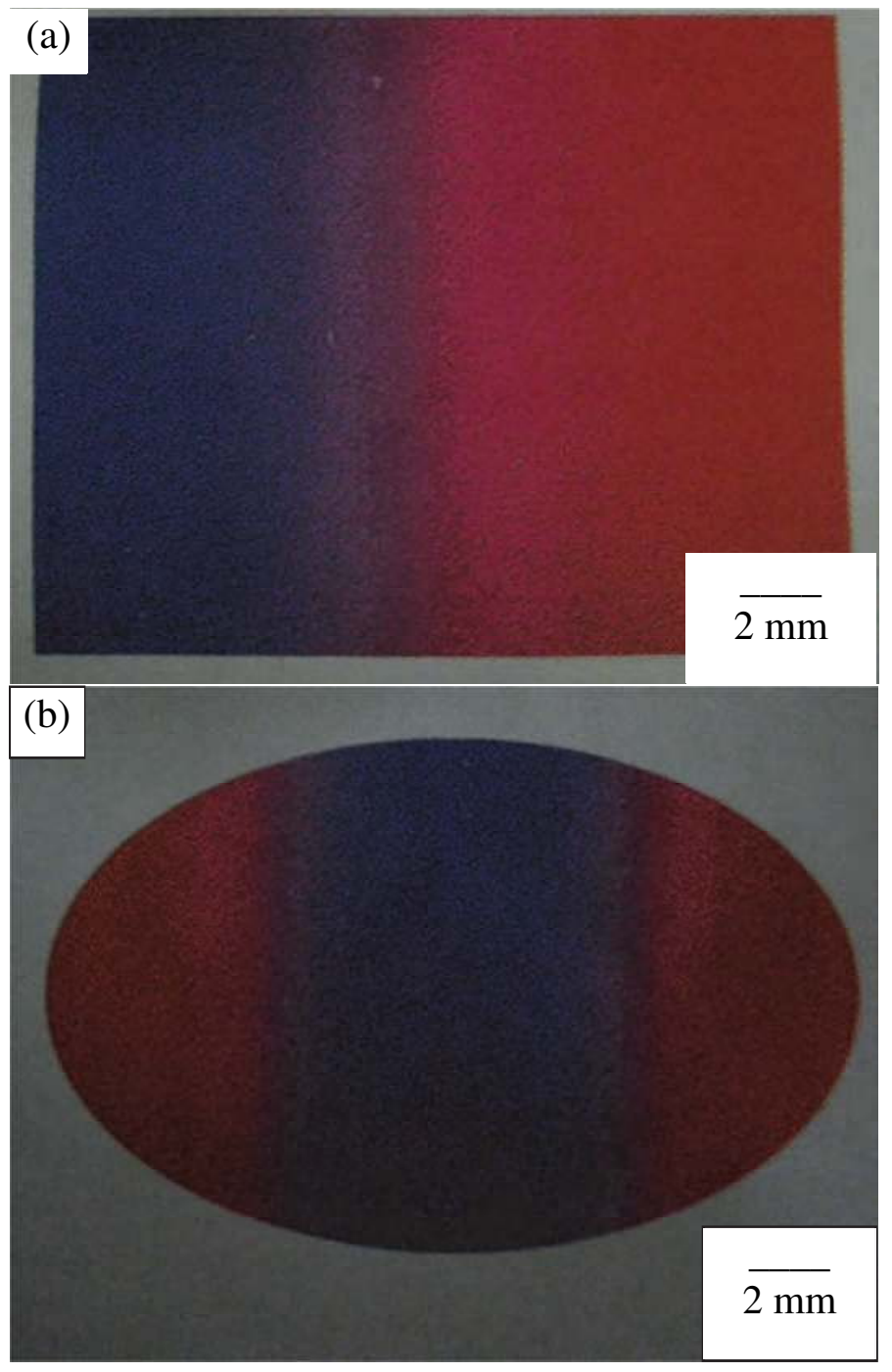

Fig. 8. Graded materials with a linear gradient of increasing tourmaline (a) from the left to the right and (b) from the centre to the edges.

The streptococcus mutans was cultured on the graded materials in Figure 8(a). The compositional profiles of the graded materials before and after culturing streptococcus mutans determined by using an energy-dispersive spectrometer are shown in Figure 9. 

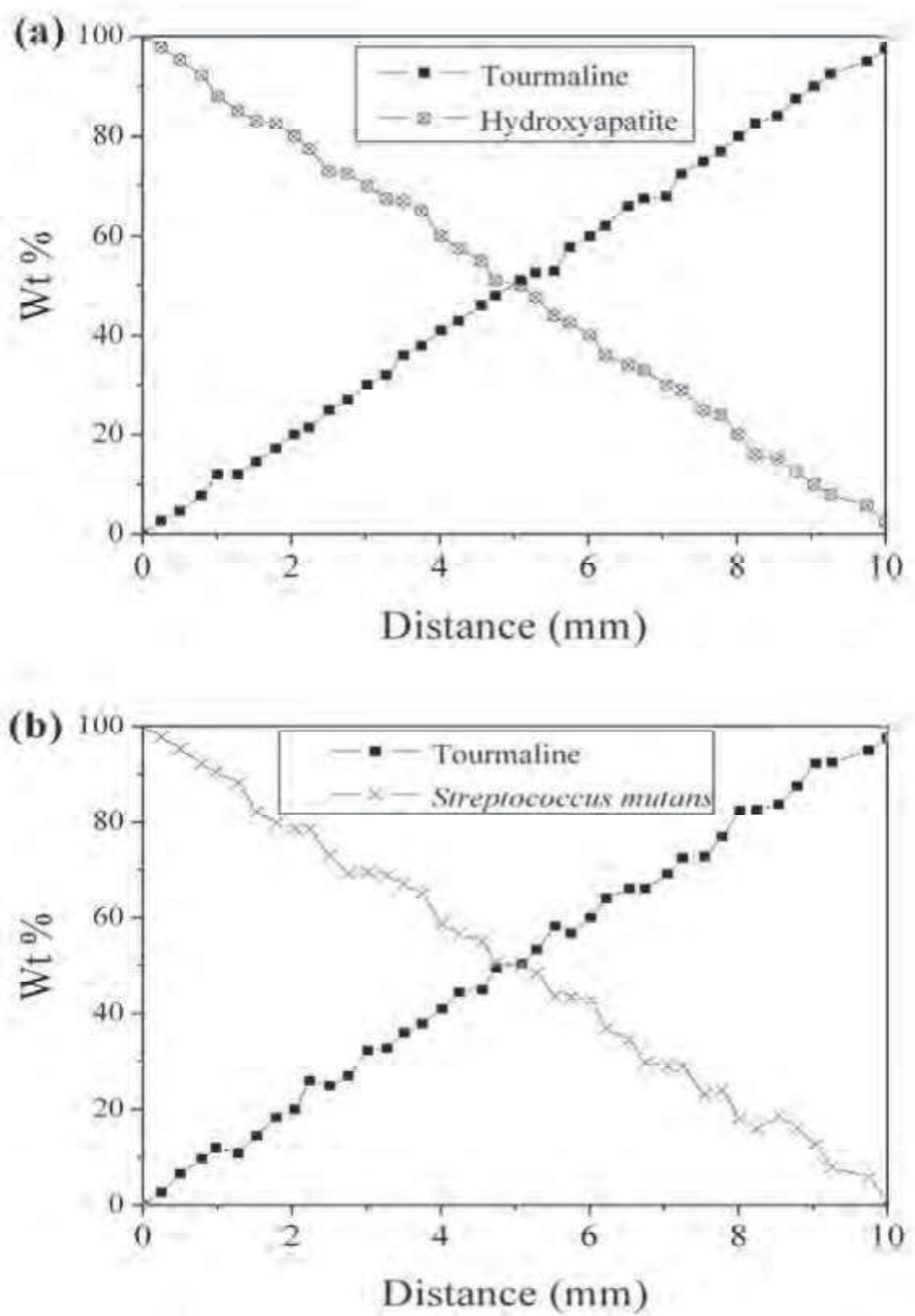

Fig. 9. Graded materials with a linear graded distribution (a) before and (b) after culturing streptococcus mutans.

As shown in Figure 9(a), before culturing streptococcus mutans, the graded compositional profiles vary in a linear distribution and match the designed composition. After cultured on the graded materials, the streptococcus mutans shows a reverse distribution to that of tourmaline (Figure 9(b)). To further investigate the effect of tourmaline on streptococcus mutans, the bacteria were exposed to $10,30,70,100,150$, and $200 \mathrm{mg} / \mathrm{ml}$ of tourmaline culture. Figure 10 shows the effect of tourmaline on the growth of streptococcus mutans. 


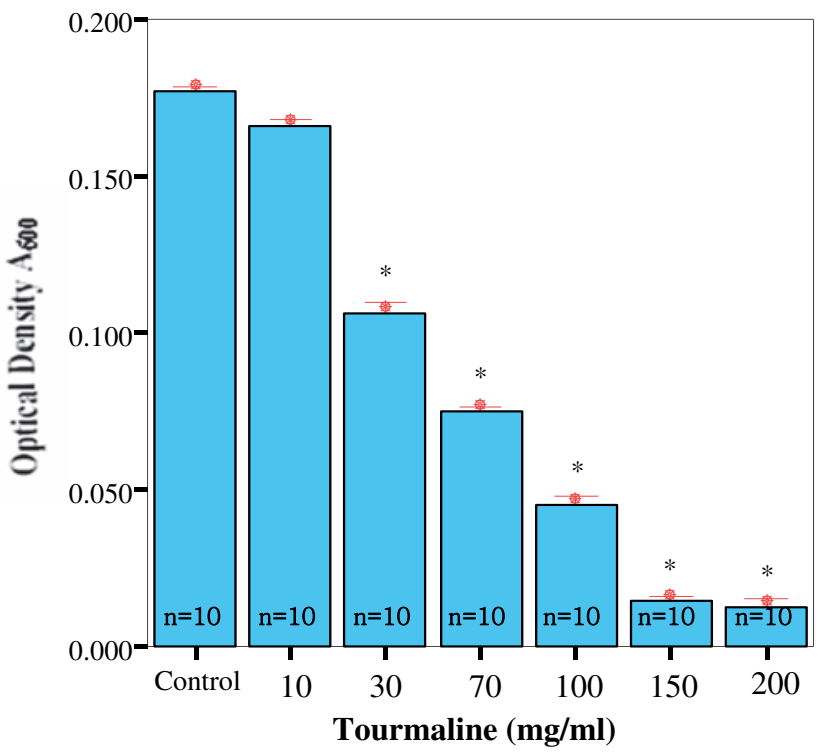

Fig. 10. Effect of tourmaline on the growth of streptococcus mutans. ${ }^{*} \mathrm{p}<0.05$ is statistically significant as determined by the Student's $t$-test for the mean values different from the control group.

The bacteria were inoculated to BHI broth with each concentration of tourmaline and anaerobically incubated for 1 day at $37^{\circ} \mathrm{C}$. The optical density of A600 was read by a spectrophotometer. From Figure 10, it can be seen that the tourmaline has an antibacterial activity against streptococcus mutans in a dose dependent manner, and exhibits significant inhibition at concentrations higher than $30 \mathrm{mg} / \mathrm{ml}$ compared to the control group $(\mathrm{p}<0.05)$. Streptococcus mutans grow in plaque, and releases various organic acids during metabolizing carbohydrates. The organic acids demineralise tooth surfaces and initiate the dental caries. The effect of tourmaline on acid production of streptococcus mutans is shown in Table 1.

\begin{tabular}{lcc}
\hline Concentration $(\mathrm{mg} / \mathrm{ml})$ & $\mathrm{n}$ & $\mathrm{pH}$ \\
\hline Control & 10 & $5.14 \pm 0.023$ \\
10 & 10 & $5.15 \pm 0.028$ \\
30 & 10 & $5.90 \pm 0.072^{*}$ \\
70 & 10 & $6.87 \pm 0.018^{*}$ \\
100 & 10 & $7.97 \pm 0.017^{*}$ \\
150 & 10 & $8.50 \pm 0.202^{*}$ \\
200 & 10 & $8.52 \pm 0.130^{*}$ \\
\hline
\end{tabular}

Note: * $\mathrm{p}<0.05$ was statistically significant as determined by the Student's $t$-test for the mean values different from the control group.

Table 1. Effect of tourmaline on acid production of streptococcus mutans. 
The decrease of $\mathrm{pH}$ was significantly inhibited in the presence of tourmaline (30-200 $\mathrm{mg} / \mathrm{ml}$ ) compared to the control group. Except antibacterial activity of tourmaline, the reason may be that the strong electric field of tourmaline would affect the water molecule in the culture and produce plenty of negative ions, which can neutralize the organic acid in the culture.

The comparison of Figure 8 and Table 1 clearly shows that the antibacterial performance of tourmaline has the similar tendency of increasing $\mathrm{pH}$ value of the bacterial suspensions. This result gives the support to the suggestion given by Dashper and Reynolds (Dashper and Reynolds, 2000) that streptococcus mutans exhibit significantly lower maximum culture OD at $\mathrm{pH} 7.1$ compared with at $\mathrm{pH} 6.0$ and 6.3.

The $\mathrm{pH}$ value is very important for the growth and metabolism of bacteria (Xia et al., 2006; Matsumoto et al., 1999). In what follows, we will give the mechanism by which tourmaline acts on the inhibition of streptococcus mutans from the view of $\mathrm{pH}$ value.

Figure 11 shows the effect of tourmaline on the different $\mathrm{pH}$ values of the bacterial suspensions.

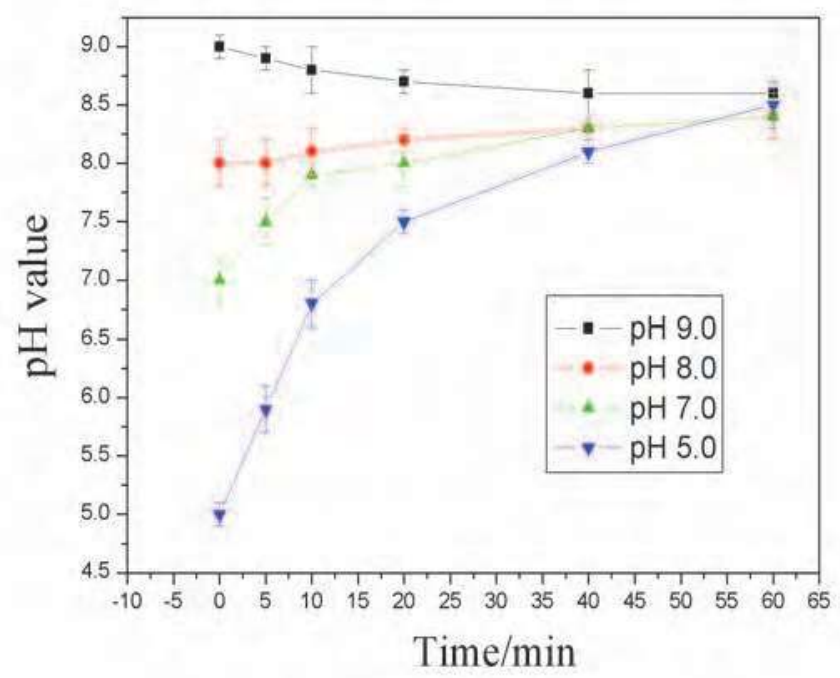

Fig. 11. Effect of tourmaline on the different $\mathrm{pH}$ values of the bacterial suspensions.

In Figure 11, 15 grams of tourmaline were added with $100 \mathrm{ml}$ of bacterial suspensions. The initial $\mathrm{pH}$ of the medium was changed between 5.0 and 11.0, whereas the temperature was constant at $37^{\circ} \mathrm{C}$.

It can be seen that the $\mathrm{pH}$ value was shifted toward 8.5 irrespective of whether it was acidic or alkaline. The increase rate of $\mathrm{pH}$ value in acidic solution was than the decrease rate in basic solution. Surface adsorption and ion exchange adsorption of $\mathrm{H}^{+}$helped the increase rate of $\mathrm{pH}$ value in acidic solution more than the decrease rate in basic solution.

The electrode characteristics of tourmaline particles influenced the redox potential of water and regulated the $\mathrm{pH}$ value of solution to about 8.5, which was consistent with the results of 
Yoshitake et al. (Yoshitake et al., 1996), Zhan et al. (Zhan et al., 2006) and Xia et al. (Xia et al., 2006). The mechanism of which is that the streptococcus mutans was remained in the culture of $\mathrm{pH}$ at about 8.5 self-adjustment induced by tourmaline. The maintenance of $\mathrm{pH}$ value was very important for the growth and metabolism of bacteria. This culture inhibits growth and acid production of streptococcus mutans.

\section{Conclusions}

In this chapter, the graded biomaterial can be fabricated by inkjet printing. Moreover, to the best of our knowledge, this study is the first to use self-adjustment $\mathrm{pH}$ value property of tourmaline for inhibiting the growth and acid production of streptococcus mutans. As the results show, tourmaline can inhibit the growth and acid production of streptococcus mutans, and exhibits significant inhibition at concentrations $30 \sim 200 \mathrm{mg} / \mathrm{ml}$, resulting from $\mathrm{pH}$ at about 8.5 self-adjustment induced by tourmaline. Therefore, this material has an inhibitory effect on streptococcus mutans, and can be used as a promising biomaterial for preventing human teeth from caries.

\section{Acknowledgements}

The authors would like to thank the "211" Project of Hebei University of Technology, and the Natural Science Foundation of Hebei Province under Grant Numbers: E2004000052 and E2006000039, and the National Natural Science Foundation of China under Grant Number: 60973079, for the financial support.

\section{References}

Sachlos, E., Reis, N., Ainsley, C., Derby, B., and Czernuszka, J.T., (2003). Novel Collagen Scaffolds with Predefined Internal Morphology Made by Solid Freeform Fabrication, Biomaterials, Vol. 24, No. 8, 1487-1497

Leong, K.F., Cheah, C.M., and Chua, C.K., (2003). Solid Freeform Fabrication of Threedimensional Scaffolds for Engineering Replacement Tissues and Organs. Biomaterials, Vol. 24, No. 13, 2363-2378

Kim, H.C., Choi, K.H., Doh, Y.H., and Kim, D.S., (2009). Fabrication of Parts and Their Evaluation Using a Dual Laser in the Solid Freeform Fabrication System. Journal of Materials Processing Technology, Vol. 209, No. 10, 4857-4866

Dwivedi, R. and Kovacevic, R., (2004). Automated Torch Path Planning Using Polygon Subdivision for Solid Freeform Fabrication Based on Welding. Journal of Manufacturing Systems, Vol. 23, No. 4, 278-291

Cai, K., Guo, D., Huang, Y., and Yang, J., (2003). Solid Freeform Fabrication of Alumina Ceramic Parts through a Lost Mould Method. Journal of the European Ceramic Society, Vol. 23, No. 6, 921-925

Tian, J., Zhang, Y., Guo, X., and Dong, L., (2002). Preparation and Characterization of Hydroxyapatite Suspensions for Solid Freeform Fabrication. Ceramics International, Vol. 28, No. 3, 299-302

Guo, D., Cai, K., Nan, C., Li, L.T., and Gui, Z.L., (2002). Gelcasting based solid freeform fabrication of piezoelectric ceramic objects. Scripta Materialia, Vol. 47, No. 6, 383387 
Cawley, J.D., (1999). Solid Freeform Fabrication of Ceramics. Current Opinion in Solid State and Materials Science, Vol. 4, No. 5, 483-489

Calvert, P., O'Kelly, J., and Souvignier, C., (1998). Solid Freeform Fabrication of Organicinorganic Hybrid Materials. Materials Science and Engineering: C, Vol. 6, No. 2-3, 167-174

Alimardani M. and Toyserkani, E., (2008). Prediction of Laser Solid Freeform Fabrication Using Neuro-fuzzy Method. Applied Soft Computing, Vol. 8, No. 1, 316-323

Alemohammad, H., Toyserkani, E., and Paul, C.P., (2007). Fabrication of Smart Cutting Tools with Embedded Optical Fiber Sensors Using Combined Laser Solid Freeform Fabrication and Moulding Techniques. Optics and Lasers in Engineering, Vol. 45, No. 10, 1010-1017

Li, X.X., Wang, J.W., Shaw, L.L., and Cameron, T.B., (2005). Laser Densification of Extruded Dental Porcelain Bodies in Multi-material Laser Densification Process," Rapid Prototyping Journal, Vol. 11, No. 1, 52-58

Bryant, Frances D., Sui, G., Leu, Ming C., (2003). A Study on Effects of Process Parameters in Rapid Freeze Prototyping, Rapid Prototyping Journal, Vol. 9, No. 1, 19-23

Xu, A.P., Qu, Y.X., Wang, J.W., and Shaw, L.L., (2005). Design for Solid Freeform Fabrication of Dental Restoration. Proceedings of the International Conference on Mechanical Engineering and Mechanics in Nanjing, China, October 26-28, 1216

$\mathrm{Xu}$, A.P. and Shaw, L.L., (2005). Equal Distance Offset Approach to Representing and Process Planning for Solid Freeform Fabrication of Functionally Graded Materials. Computer- Aided Design, Vol. 37, No. 12, 1308-1318

Calvert, P., (2007). Inkjet Printing Technology Offers a Way to Create Three-dimensional Biological Structures for Studying Cell Interactions and Artificial Organs. Science, Vol. 318, 208-209

Xu, T., Gregory, C.A., Molnar, P., Cui, X.F., Jalota, S., Bhaduri, S.B., and Boland, T., (2006). Viability and Electrophysiology of Neural Cell Structures Generated by the Inkjet Printing Method. Biomaterials, Vol. 27, No. 19, 3580-3588

Saunders, R.E., Gough, J.E., and Derby, B., (2008). Delivery of Human Fibroblast Cells by Piezoelectric Drop-on-demand Inkjet Printing. Biomaterials, Vol. 29, No. 2, 193-203

Sanchez, V., Madec, M.B., and Yeates, S.G., (2008). Inkjet Printing of 3D Metal-insulatormetal Crossovers. Reactive and Functional Polymers, Vol. 68, No. 6, 1052-1058

Roth, E.A., Xu, T., Das, M., Gregory, C., Hickman, J.J., and Boland, T., (2004). Inkjet Printing for High-throughput Cell Patterning. Biomaterials, Vol. 25, No. 17, 3707-3715

Hasenbank, M.S., Edwards, T., Fu, E., Garzon, R., Kosar, T.F., Look, M., Mashadi-Hossein, A., and Yager, P., (2008). Demonstration of Multi-analyte Patterning Using Piezoelectric Inkjet Printing of Multiple Layers. Analytica Chimica Acta, Vol. 611, No.1, 80-88

Cui X. and Boland T., (2009). Human Microvasculature Fabrication Using Thermal Inkjet Printing Technology. Biomaterials, Vol. 30, No. 31, 6221-6227

Wang, J. and Shaw, L.L., (2006). Fabrication of Functionally Graded Materials via Inkjet Color Printing. Journal of the American Ceramic Society, Vol. 89, No. 10, 3285-3289

Tooth anatomy, http://www.mydr.com.au/first-aid-self-care/tooth-anatomy, being valid as of April 2011. 
Namba, T., Tsunezuka, M., and Hattori, M., (1982). Dental Caries Prevention by Traditional Chinese Medicines. Part II. Potent Antibacterial Action of Magnoliae Cortex Extracts against Streptococcus Mutans. Planta Medica, Vol. 44, No. 2, 100-106

Jessica Welin-Neilands and Gunnel Svensäter, (2007). Acid Tolerance of Biofilm Cells of Streptococcus Mutans. Applied and Environmental Microbiology, Vol. 73, No. 17, 5633-5638

Ooshima, T., Osaka, Y., Sasaki, H., Osawa, K., Yasuda, H., Matsumura, M., Sobue, S., and Matsumoto, M., (2000). Caries Inhibitory Activity of Cacao Bean Husk Extract in Invitro and Animal Experiments. Archives of Oral Biology, Vol. 45, No. 8, 639-645

Hefferren, J.J., Koehler, H.M., Foods, Nutrition and Dental Health. Park Forest South, IL: Pathotox Publishers; 1981, p.138.

Thylstrup, A., Fejerskov, O., Textbook of Cariology. Denmark, Munksgaard: Copenhagen; 1986. 145-146.

Nakajo K., Imazato S., Takahashi Y., Kiba W., (2009). Fluoride Released from Glass-ionomer Cement is Responsible to Inhibit the Acid Production of Caries-related Oral Streptococci. Dent. Mater., Vol. 25, No. 6, 703-708

Scherp, H.W., (1971). Dental Caries: Prospects for Prevention. Science, Vol. 173, No. 4003, 1199-1205

Allaker, R.P., Douglas, C.W.I., (2009). Novel Anti-microbial Therapies for Dental Plaquerelated Diseases. International Journal of Antimicrobial Agents, Vol. 33, 8-13

Shouji, N., Takada, K., Fukushima, K., and Hirasawa, M., (2000). Anticaries Effect of a Component from Shiitake. Caries Res., Vol.34, No.1, 94-98

Matsumoto, M., Minami, T., Sasaki, H., Sobue, S., Hamada, S., and Ooshima, T., (1999). Inhibitory Effects of Oolong Tea Extract on Caries-Inducing Properties of Mutans Streptococci. Caries Res., Vol. 33, No. 6, 441-445

Castañeda, C., Eeckhout, S.G., Costa, G.M., Botelho, N.F., Grave, E.D., (2006). Effect of Heat Treatment on Tourmaline from Brazil. Phys. Chem. Miner.,Vol. 33, No. 3, 207-216

Fuchs, Y., Lagache, M., Linares, J., (1998). Fe-tourmaline Synthesis under Different $\mathrm{T}$ and $f_{\mathrm{o} 2}$ Conditions. American Mineralogist, Vol. 83, 525-534

Jin, Z.Z., Ji, Z.J., Liang, J.S., Wang, J., Sui, T.B., (2003). Observation of Spontaneous Polarization of Tourmaline. Chinese Physics, Vol. 12, No. 2, 222-225

Nakamura, Terutaro, Fujishiro, Koji, Kubo, Tetujiro, Iida, Masamori, (1994). Tourmaline and lithium niobate reaction with water. Ferroelectrics, Vol. 155, No. 1-4, 207-212

Zhu, D.B., Liang, J., Ding, Y., Xue, G., Liu, L., (2008). Effect of Heat Treatment on Far Infrared Emission Properties of Tourmaline Powders Modified with a Rare Earth. Journal of the American Ceramic Society, Vol. 91, No. 8, 2588-2592

Xia, M.S., Hu, C.H., Zhang, H.M., (2006). Effects of Tourmaline Addition on the Dehydrogenase Activity of Rhodopseudomonas Palustris. Process Biochemistry, Vol. 41, No. 1, 221-225

Esgalhado, M.E., Roseiro, J.C., Collaco, M.T.A., (1995). Interactive Effects of $\mathrm{pH}$ and Temperature on Cell Growth and Polymer Production by Xanthomonas Campestris. Process Biochemistry, Vol. 30, No. 7, 667-671

XAAR, (2006). Guide to Operation of XJ126 High Performance Ink Jet Printhead. Cambridge, United Kingdom

Xaar 126 Product datasheet, http://www.xaar.com/xaar126.aspx, being valid as of April 2011. 
Shih, W.J., Chen, Y.F., Wang, M.C., Hon, M.H., (2004). Crystal Growth and Morphology of the Nano-sized Hydroxyapatite Powders Synthesized from $\mathrm{CaHPO} 42 \mathrm{H} 2 \mathrm{O}$ and CaCO3 by Hydrolysis Method. Journal of Crystal Growth, Vol. 270, No. 1-2, 211218

Dashper, S.G., and Reynolds, E.C., (2000). Effects of Organic Acid Anions on Growth, Glycolysis, and Intracellular $\mathrm{pH}$ of Oral Streptococci. J. Dent. Res., Vol. 79, No. 1, 90-96

Yoshitake, N., Ayumu, Y., Kazuya, O., (1996). pH Self-Controlling Induced by Tourmaline. Journal of Intelligent Material Systems and Structures, Vol. 7, No. 3, 260-263

Zhan, J., Ge, B., Wang, P., Wang, Z., Zheng, C., Huang, B., and Jiang, M., (2009). Study on the Microstructure of Natural Tourmaline and Mechanism of Its Influence on $\mathrm{pH}$ Value of Water. Functional Materials, Vol. 40, No. 4, 556-559 


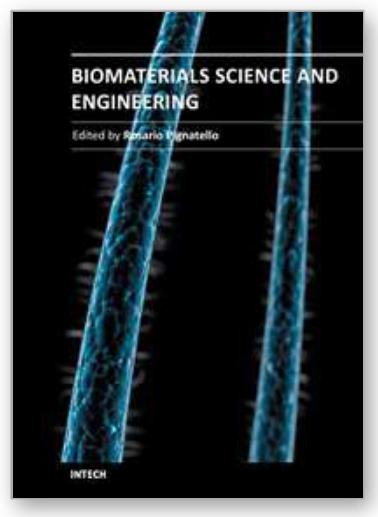

\author{
Biomaterials Science and Engineering \\ Edited by Prof. Rosario Pignatello
}

ISBN 978-953-307-609-6

Hard cover, 456 pages

Publisher InTech

Published online 15, September, 2011

Published in print edition September, 2011

These contribution books collect reviews and original articles from eminent experts working in the interdisciplinary arena of biomaterial development and use. From their direct and recent experience, the readers can achieve a wide vision on the new and ongoing potentials of different synthetic and engineered biomaterials. Contributions were not selected based on a direct market or clinical interest, than on results coming from very fundamental studies which have been mainly gathered for this book. This fact will also allow to gain a more general view of what and how the various biomaterials can do and work for, along with the methodologies necessary to design, develop and characterize them, without the restrictions necessarily imposed by industrial or profit concerns. The book collects 22 chapters related to recent researches on new materials, particularly dealing with their potential and different applications in biomedicine and clinics: from tissue engineering to polymeric scaffolds, from bone mimetic products to prostheses, up to strategies to manage their interaction with living cells.

\title{
How to reference
}

In order to correctly reference this scholarly work, feel free to copy and paste the following:

Anping Xu and Dongbin Zhu (2011). Fabrication and Antibacterial Performance of Graded Nano-Composite Biomaterials, Biomaterials Science and Engineering, Prof. Rosario Pignatello (Ed.), ISBN: 978-953-307-609-6, InTech, Available from: http://www.intechopen.com/books/biomaterials-science-and-engineering/fabricationand-antibacterial-performance-of-graded-nano-composite-biomaterials

\section{INTECH}

open science | open minds

\section{InTech Europe}

University Campus STeP Ri

Slavka Krautzeka 83/A

51000 Rijeka, Croatia

Phone: +385 (51) 770447

Fax: +385 (51) 686166

www.intechopen.com

\section{InTech China}

Unit 405, Office Block, Hotel Equatorial Shanghai

No.65, Yan An Road (West), Shanghai, 200040, China

中国上海市延安西路65号上海国际贵都大饭店办公楼 405 单元

Phone: +86-21-62489820

Fax: $+86-21-62489821$ 
(C) 2011 The Author(s). Licensee IntechOpen. This chapter is distributed under the terms of the Creative Commons Attribution-NonCommercialShareAlike-3.0 License, which permits use, distribution and reproduction for non-commercial purposes, provided the original is properly cited and derivative works building on this content are distributed under the same license. 